\title{
OPERATIONAL PERFORMANCE OF DOMESTIC AND FOREIGN-INVESTED ENTERPRISES IN CHINA
}

\author{
Dean $\mathrm{Xu}^{\mathrm{a}}$ \\ Associate Professor of Strategy \\ Guanghua School of Management \\ Peking University \\ Beijing, China 100871 \\ Telephone/Fax: (8610) 6275-5261 \\ Email: dxu@gsm.pku.edu.cn \\ Yigang Pan \\ Scotiabank Professor of International Business \\ Schulich School of Business \\ York University, and \\ Associate Professor of Marketing \\ University of Hong Kong \\ Hong Kong, SAR \\ Telephone: (852) 2857-8345 \\ Email: ypan@hkusua.hku.hk \\ Changqi Wu \\ Professor of Strategy \\ Guanghua School of Management \\ Peking University \\ Beijing, China 100871 \\ Telephone: (8610) 6275-6269 \\ Email: topdog@gsm.pku.edu.cn \\ Chi Kin (Bennett) Yim \\ Associate Professor of Marketing \\ University of Hong Kong \\ Hong Kong, SAR \\ Telephone: (852) 2857-8343 \\ Email: yim@business.hku.hk
}

\section{Journal of World Business}

May 2005

\footnotetext{
${ }^{a}$ Corresponding author. We wish to thank Hansheng Wang and Junni Zhang for helpful suggestions, as well as Yuping Zeng for excellent research assistance.
} 


\title{
OPERATIONAL PERFORMANCE OF DOMESTIC AND FOREIGN-INVESTED ENTERPRISES IN CHINA
}

\begin{abstract}
Despite increasing attention paid to China's enterprise reform since the late 1970s, relatively little is known about the performance of the reformed SOEs and newly formed private firms visa-vis foreign firms in China. In this study, we examine the operational performance of domestic Chinese firms in various ownership categories versus foreign-invested enterprises based on two nation-wide Industrial Censuses conducted by the National Bureau of Statistics in 1998 and 2002. We found that domestic firms in the non-state sector and foreign-invested enterprises both performed better than the SOEs. Meanwhile, evidence shows that three categories of Chinese firms - the privately owned enterprises, the collectively owned enterprises, and the shareholding firms, had higher performance levels than the foreign-invested firms.
\end{abstract}

Key Words: Ownership Reform, Chinese Firms, Foreign-Invested Enterprises 
Reform in China began in the late 1970's. Since then, China has embarked on a path of rapid economic growth. China's GDP in 2003 reached US\$1.3 trillion in absolute dollar terms, making it the sixth largest economy behind the United States, Japan, Germany, Britain and France. The breathtaking growth is believed to have come from two main sources, namely the reformed state-owned enterprises (SOEs), now in the non-state sector, and the foreign-invested enterprises (FIEs). Other than anecdotal accounts, however, few studies have empirically examined the relative performance of various types of firms in China on a scale large enough to present an overall picture.

There are signs pointing to the increasing competitiveness of Chinese firms (Zeng \& Williamson, 2003). By 2002, ten of them appeared on the list of Fortune's largest global 500 firms. For example, Haier, a former SOE and now a shareholding company with majority state ownership, achieved an annual sales of US\$7 billion in 2001, catching up to that of US\$10 billion of Whirlpool. Haier not only had secured the domestic Chinese markets for major household appliances, but also had extended the competition to the US market by opening up a manufacturing facility in South Carolina with a capacity of half a million refrigerators in 2002. At the same time, Lenovo, a shareholding company headquartered in Beijing, outperformed Dell, Compaq, and IBM to become the largest computer manufacturer in Asia. Its recent acquisition of IBM's personal computer business has made it the third-largest PC maker in the world. In the mobile phone market, domestic firms captured a 50 percent market share in 2003 at the expense of Motorola, Nokia, and Ericsson in China.

On the other hand, there are signs pointing to performance discrepancy among Chinese firms. As the market-oriented reform continues, China moves towards a mixed economy, in which the SOEs, non-SOEs, and FIEs co-exist, although the state sector represents a decreasing 
share in term of total output. Whereas SOEs accounted for $77.7 \%$ of China's industrial output in 1978 , they accounted for only about $28.5 \%$ by 1998 . Through the reform, the private sector flourished and gained momentum, but the state sector has not addressed effectively the old problems (Lin, Cai, \& $\mathrm{Li}, 1998$ ). It is important to know how the majority of firms in the nonstate sector, as opposed to such stars as Haier and Lenovo, compare with SOEs and FIEs.

There is evidence of increasing commitment of multinational firms in China (Li, Qian, Lam, \& Wang, 2000). By March 2003, a total of 432,820 foreign-invested enterprises had been approved to set up their operations in China, with a cumulative actual investment of US\$461 billion. After China's accession to the World Trade Organization in December 2001, inflows of foreign investments in China increased rapidly. A total number of 8,624 FIEs were approved in the first quarter of 2003, an increase of $36.6 \%$ from the same period in 2002 . The total realized foreign investment was US\$13 billion, an increase of 56.7\% from the same period in 2002 . While the overall statistics on capital inflows are impressive, there is a lack of comprehensive understanding of the operational performance of multinational firms in China. The profitability of multinational firms with certain country origins is reportedly on the decline (Pan \& Chi, 1999). Further, it appears that multinational firms are abandoning their long-standing strategy of entering China through equity joint ventures (EJVs) (Vanhonacker, 1997). Thus it is important to evaluate the performance of FIEs as a whole in China, as well as to assess the relative advantages of EJVs and wholly owned subsidiaries (WOSs).

The goal of this study is to examine and compare the operational performance of Chinese and foreign-invested enterprises in different ownership categories. We are particularly interested in knowing whether, after years of ownership reform, the former SOEs and new firms in the nonstate sector have gained competitiveness vis-a-vis foreign-invested enterprises, and will 
formulate basic hypotheses addressing this research question. Our statistical tests rely on data obtained from two official large-scale surveys of firms conducted in China in 1998 and 2002. Because these surveys included tens of thousands of domestic and foreign firms, we are able to draw a general picture of the relative performance of these firms with a moderate degree of confidence. We believe that results of this study will be useful to a number of interested parties, including domestic Chinese firms, multinational firms inside or considering to enter China, as well as international investors looking for opportunities in the emerging markets. Our major finding - that some categories of Chinese firms have outperformed the foreign-invested enterprises - is counter-intuitive, and should prompt multinational firms to rethink about their own competitiveness in anticipation of more fierce competition ahead in the China market.

\section{THE OWNERSHIP REFORM AND DOMESTIC CHINESE ENTERPRISES}

The transition from a centrally planned economy towards a market-oriented economy has been a gigantic economic, political, and social experiment in China in the past quarter of a century. The reform of state-owned enterprises is at the center of this transition. The first wave of reform was for the state to delegate power to SOEs and permit them to retain part of the profits. This reform was carried out from 1978 to 1986. Due to increased autonomy and external competitive pressures, most SOEs improved their efficiency. However, deep-rooted problems remained. Then, between 1987 and 1996, the attention was shifted to transforming the operating mechanisms of those enterprises. Some SOEs began to adopt the corporate structure and management systems of Western corporations. From 1997, the issue of ownership reform was brought into the limelight. Privatization of SOEs and other means of reform were formally permitted and implemented. 
The ownership reform gathered its pace in the late 1990s because the Chinese government found it increasingly harder to keep the SOEs afloat. In 1998, for instance, the state sector required a government subsidy of 150 billion yuan, or US\$18.3 billion (O’Neill, 1999). More and more people started to believe that state ownership was the root cause of all the ills of SOEs, and that a well-thought-out ownership structure and management system would save these firms. From a more practical perspective, the central government was forced to allow the SOEs to raise the needed capital from non-state sources, thus opening the door to privatization. By 2002, the central government had adopted the policy of "grasping the large and releasing the small." Under this policy, the government retained direct control over some largest SOEs and infused additional capital in a hope to make these consolidated industrial enterprises more competitive. Meanwhile, the state has relinquished the small and medium-sized SOEs to the nonstate sector through equity sales, auctions, management buyouts, employee shareholder options, and other means.

SOEs have been transformed into three major types of new ownership. The first category is shareholding enterprises. Ownership of these firms is open to all parties, including the state, the employees, and private investors. This is the basic form of modern corporations in the West. To ensure the plurality of shareholders, the Chinese government requires a shareholding company to have a minimum of five stockholders, which may or may not include the state, with no maximum limit. The ultimate goal is to turn the SOEs into companies with modern ownership and management systems. When these SOEs become profitable and attractive to private investors both in China and abroad, they will go for public listing in the stock markets. Many of these enterprises have already been listed on the stock exchanges of Shanghai, Shenzhen, Hong Kong, and even New York. 
The second category is limited liability firms. Ownership of these firms still lies in the hands of the state, but the state allows them to have a higher level of autonomy. The state is no longer its unlimited creditor. If the firm suffers from unrecoverable losses, the state may let it go bankrupt. This type of reform forces the SOEs to be separated from the state and become independent business entities. They were not turned into shareholding firms, either because there has not been enough capital from the private sources, or because the state wants to keep these enterprises in particular segments and does not intend to privatize them entirely. Even though the enterprise is still state-owned, the state refrains from giving direct orders on managerial and operational issues (Nee \& Matthews, 1996). Thus we treat these firms as non-SOEs.

The last category is privatized SOEs. The ownership of these firms is now privately controlled. In other words, the state has sold these former SOEs to private investors, which may or may not include managers and employees of the firm, at a price. Typically they have been transformed from smaller SOEs. Whether this type of reform, especially when done through management buyouts (MBOs), should be carried out on a larger scale and applied to larger SOEs, is under hot debate in the Chinese society. ${ }^{1}$

\section{PERFORMANE OF DOMESTIC AND FOREIGN FIRMS IN CHINA}

\section{Domestic Firms versus Foreign-Invested Enterprises}

Reform and open-door policy are two backbones of Chinese economic growth in the past quarter of a century. Whereas reform, especially ownership reform since the late 1990s, has caused some fundamental changes to the domestic Chinese firms internally, the astounding increase in the inflow of foreign direct investments (FDI) facilitated these changes externally, as well as reshaped the competitive landscape of the China market as a whole. By 2003, the amount of FDI intake was well above US\$ 50 billion. 
While researchers have examined performance of foreign-invested firms in China (e.g. Pan, Li, \& Tse, 1999; Luo \& Peng, 1999), they have seldom done so in comparison with domestic Chinese firms. The lack of large-scale empirical investigation into the relative performance of domestic and foreign-invested firms in China caused controversies about the effect of FDI in China on the competitiveness of Chinese firms. Some scholars started to express concerns over the negative impact of FDI on Chinese firms and industries in recent years. Huang (2003), for instance, held that the flourish of FDI has been achieved at the sacrifice of China's private sector. This view is being shared by an increasing number of scholars and practitioners. ${ }^{2}$

Behind such concerns is the conventional belief that domestic Chinese firms are at a significant competitive disadvantage vis-à-vis multinational firms. This view has intuitive appeals, and is supported by numerous cases in the early days of economic reform and open-door policy. Thus even though it is widely know that multinational firms face a "liability of foreignness", i.e. having to incur higher costs than local firms (Hymer, 1976), in a foreign country, people had no doubt that the performance levels of domestic and foreign firms in China were not comparable to each other. Twenty years later, however, the answer is no longer straightforward. On the one hand, many Chinese firms have made progress through the reform and by directly competing with the multinationals. On the other hand, multinational firms should also have made progress by accumulating local knowledge and host-country experience (Luo \& Peng, 1999; Steensma \& Lyles, 2000). In fact, a brief survey of some major theories in economics, organization, and strategic management suggests that the analysis can be rather complicated. We discuss four relevant perspectives below. As Table 1 shows, each of them emphasizes a different factor in explaining firm competitiveness. 
Table 1. Relative Advantages of SOEs, Non-SOEs, and FIEs

\begin{tabular}{l|ccc}
\hline \multicolumn{1}{c|}{ Key Factors } & $\begin{array}{c}\text { State-Owned } \\
\text { Enterprises }\end{array}$ & $\begin{array}{c}\text { Non-SOEs/ } \\
\text { Reformed SOEs }\end{array}$ & $\begin{array}{c}\text { Foreign-Invested } \\
\text { Enterprises }\end{array}$ \\
\hline Agency Costs & High & Low & Low-Medium \\
Transaction Costs & High & Low & Low-Medium \\
Resources/Capabilities & Medium & Low & High \\
Legitimacy & Medium & Medium & Medium \\
\hline
\end{tabular}

Agency theory. Understandably, agency theory is a perspective that is closely related to the logic of ownership reform. Traditional agency theory focuses on the agency problem that typically exists in the private sector due to the separation of ownership and control (Fama \& Jensen, 1983). The problem is especially severe in modern corporations, where the principals lack the motivation to monitor the agents because of a dispersed ownership structure (Demsetz, 1983). In the case of a state-owned enterprise, although ownership is not dispersed, the "principal" becomes the state, represented by bureaucrats from different governmental organizations and at different levels. These bureaucrats, themselves "agents" of the state, lack accountability and enough incentives to closely monitor SOE managers (Qian, 1996), as they are not adequately rewarded or penalized in accordance with the performance of the SOEs (Ma \& Young, 2001). Thus ownership by all of the people becomes ownership by none of the people (Perkins, 1994). The ownership reform and the privatization of SOEs were aimed at changing this situation by reducing agency costs, channeling private wealth as capital for firm growth, and introducing corporate and private investors who will make the managers more accountable.

Agency theory also has important implications for multinational firms, particularly for their overseas operations. It has been argued that the headquarters-foreign subsidiary relationship of a multinational firm resembles a principal-agency structure (Nohria \& Ghoshal, 1994). The agency problem exists because there are goal incongruence and information asymmetries 
between the headquarters and the subsidiaries located in a host country (Roth \& O'Donnell, 1996). For example, subsidiary managers may have specialized local knowledge that is not shared by managers at the headquarters, and may develop their own strategic priorities independent of corporate-level policies (Birkinshaw \& Hood, 1998). Thus monitoring behavior and evaluating performance become a difficult task for the multinational firms, especially for their subsidiaries in China, because of opportunism and low trust in the local business environment. As a result, many multinational firms have to place their China subsidiaries under direct monitoring by the headquarters, thus limiting the strategic flexibility at the subsidiary level.

Transaction cost theory. In a modern enterprise, capital, technology, skills, and assets of various kinds come from different sources. The operation of the enterprise consists of various transactions among owners, employees, clients, and business partners (Williamson, 1985). Each party is seeking to maximize its own utility, and constantly looking for better opportunities. Transaction costs theory proposes that enterprises exist because they can handle transactions more efficiently than through the market mechanism. In light of this theory, SOEs are inefficient because they include within the organization transactions that can be better handled by the market. For example, large SOEs undertake policy burdens such as retaining redundant workers and providing welfare benefits (Lin \& Tan, 1999), and therefore are encouraged to diversify and grow into a mini-society by having their own schools and hospitals. The reform of SOEs hinges on delineating what SOEs should do internally and externally. Through the reform, the more efficient forms of organization will gradually drive out the inefficient SOEs.

Transaction cost theory and its extension in the international area, internalization theory, suggest that it is more efficient (less costly) for a firm to use hierarchies rather than market intermediaries to serve a foreign country (Beamish \& Banks, 1987; Buckley \& Casson, 1976). In 
an emerging market such as China, foreign-invested enterprises have to deal with market imperfections, just like local firms, and sometimes even more so. For instance, they have to develop country-specific assets in an environment where uncertainty level is high, and deal with local suppliers and buyers where opportunistic behavior is common. On the other hand, FIEs enjoy an advantage over local firms in the form of an internal market within their multinational corporate networks (Ghoshal \& Bartlett, 1990), although this may in turn increase their internal transaction costs due to such factors as large geographic distances and higher demand on information processing.

Resource/capability perspectives. These perspectives attribute competitiveness to the resource endowment and internal capabilities of the firm (Prahalad \& Hamel, 1990; Wernerfelt, 1984). Resources must be rare, valuable, imperfectly imitable, and non-substitutable in order for a firm to reap economic rents (Barney, 1991). Because of the short history of China's market economy, Chinese firms generally have not developed such resources, or unique competences, which will help confer a competitive advantage. In contrast, FIEs are able to utilize the ownership advantages of their parent firms in competing with local firms (Dunning, 1981). These may include proprietary assets such as technological know-how and brand names, managerial practices and organizing routines, and strong corporate cultures. Furthermore, multinational firms can gradually develop host-country-specific knowledge through learning from local partners and competitors (Delios \& Beamish, 2001), thus enlarging the competence gap between foreign and local firms.

On the other hand, while foreign-invested firms in China typically enjoy a resource or capability-based advantage over local firms, the latter may have access to some "network resources" not shared by the former. For instance, research has long regarded guanxi as a key 
source of competitive advantage in the Chinese context (Tsang, 1998). Although it is argued that personal guanxi is more important to private firms than to state-owned enterprises, this is only true because SOEs have more formal and official network resources than private firms (Peng \& Luo, 2000). A notable aspect of such resources is SOE managers' connections to the central ministries (Shenkar, 1990). Overall, one can argue that while domestic Chinese firms lag behind FIEs in terms both resources and competences, some Chinese firms, especially SOEs, also enjoy unique network resources, along with associated reduction in transaction costs, that may bring them a competitive advantage vis-à-vis the multinationals.

Institutional theory. Many phenomena that could not be explained by rational economic models exist because of various institutional forces at work (DiMaggio \& Powell, 1983; Meyer \& Rowan, 1977). Institutional theory emphasizes the role of isomorphism in shaping firm behavior. A firm that conforms to the formal and informal rules, cultural norms, and implicit assumptions of the society is expected to earn legitimacy and social capital, thus able to ensure its own survival, even though it may not be organized in the most efficient way from the economic perspectives (Scott, 1995). In a transition economy such as China, socialist values and traditions form part of the formal rules through government directives in economic activities, as well as part of the informal rules by influencing managerial practices and routines. Thus, for example, retaining an unnecessarily large workforce might be seen as a firm's contribution to the attainment of the central or local government's economic goals. A firm that conforms to such an expectation might be rewarded by being granted access to bank loans and other financial resources, although from a transaction cost perspective, the firm may be close to bankruptcy. In this tradition, SOEs clearly enjoy more legitimacy than their counterparts in the various non-state sectors, and thus are able to sustain themselves despite obvious economic inefficiencies. 
In a transition economy, however, the rules of the game (North, 1990) are gradually changing, and the old routines being deinstitutionalized. New institutional rules and forces compete with the old ones to become the dominant voice of the society. One such force is the norms of reform, entrepreneurial growth, and profit maximization among firms in the private sector. Another force is professional management and global standard represented by foreigninvested firms. Institutional theory suggests that, facing multiple and sometimes conflicting demands, each firm is likely to choose to conform to the ones that best suit its own interests (Oliver, 1991). As it stands now, each group of firms - SOEs, non-SOEs, and FIEs - is consistent with some institutional demands but not with some others. The SOEs still have substantial support from the government but are under increasing pressures to reform. The nonSOEs are gaining acceptance but in many instances habitually disadvantaged in the Chinese economy and society (Nee, 1992). The multinational firms, as a vehicle that brought advanced technology and management skills to China as well as contributed to the economic growth of this country, have generally enjoyed legitimacy. On the other hand, their popularity in the society is declining as China becomes more and more open to the world economy, and as Chinese firms seeking growth face increasing competition from the multinationals. The FIEs also suffer from the conflicting demands caused by incompatible institutional rules of their home and host countries (Kostova \& Zaheer, 1999; Xu \& Shenkar, 2002). Sometimes local legitimacy can only be achieved at the cost of operational efficiency within the multinational firm system (Westney, 1993).

Summary. The above survey covers some major theoretical perspectives that are commonly used in a transition economy context (Hoskisson, Eden, Lau, \& Wright, 2000; Meyer \& Peng, 2005). Although Table 1 has suggested some directions for analysis, it would be 
premature to reach clear-cut conclusions as to the relative advantages and performance of the three broad categories of firms in China based on any single perspective listed here. Generally speaking, SOEs incur higher transaction and agency costs and are the least efficient organizations. Non-SOEs, including reformed former SOEs, have corrected many of the problems associated with the SOEs. They lack the same support and access to resources, however, as their SOE counterparts. FIEs are organized after their parents - some of them being the most efficient and resourceful organizations in the world. But they encounter unique problems in an environment far away from their home countries. Combining these various perspectives and considerations, we make the following preliminary predictions:

\section{Hypothesis 1: On average, firms in the non-state sectors perform better than state- owned enterprises in China.}

\section{Hypothesis 2: On average, foreign-invested enterprises perform better than domestic Chinese firms.}

\section{Equity Joint Ventures and Wholly-Owned Subsidiaries}

A long-standing theme in international management is the advantages of equity joint ventures in comparison to wholly owned subsidiaries. The success of EJVs in China has been well documented (Beamish, 1993; Luo, 1997; Pan et al., 1999). In recent years, however, the trend is being reversed. More and more multinational firms have chosen to enter China with WOSs in stead of EJVs because of problems associated with the latter. The number of newly established WOSs exceeded that of the new EJVs for the first time in 1997 (Child \& Tse, 2001). Among other things, EJVs are plagued by internal conflicts, are hard to sustain, and cannot guarantee access to an administratively divided national market (Walsh, Wang, \& Xin, 1999; Vanhonacker, 1997). The business media in China are full of reports on the "equity unilateralization" by the foreign partners in Sino-foreign joint ventures. Even such pioneer in 
EJV experiments as Matsushita has bought up the equity stakes of its Chinese partners and formed its wholly owned China headquarters. Such reports, however, are mostly anecdotal and yet to be confirmed through statistical analysis.

Many theories can provide insights into the relative performance of EJVs and WOSs in the Chinese economy today. We rely on the same set of perspectives in Table 1 to make our prediction. Although not widely used for this purpose, agency theory suggests that agency costs are probably higher in EJVs because more principals (parents) and agents (managers representing these parents) are involved, and hence higher chances for goal incongruence between partners, more complicated task for monitoring behavior, and increased difficulty in evaluating performance (Luo, Shenkar, \& Nyaw, 2001). The transaction cost - internalization perspective, on the other hand, generally favors the EJV as a more efficient mode of organizing in transition economies, mainly because this mode reduces transaction costs related to imperfect market institutions (Meyer, 2001; Meyer \& Peng, 2005).

The resource and capability perspectives suggest that compared to a WOS, an EJV may benefit from both parents and thus enjoy a certain level of advantage. Combining complementary resources and capabilities has been an important rationale for joint ventures formation. A typical joint venture in transition economies consists of distinctive contributions made by both the foreign and local parents - usually technological and managerial skills from the foreign parent, and access to distributional channels and markets from the local partner. The success of an EJV often lies in its capacity to absorb knowledge transferred from its foreign parent (Lane, Salk, \& Lyles, 2001; Lyles \& Salk, 1996), as well as its ability to learn from the local business community (Makino \& Delios, 1996). In this sense, an EJV has more resources and opportunities for growth and success than a WOS. 
Lastly, institutional theory provides insights into this issue from a non-efficiency perspective. This theory suggests that having a local partner in the host country is an effective mechanism for lowering the risk of institutional conflicts between a foreign subsidiary and the host country institutions (Xu, Pan, \& Beamish, 2004). On the other hand, this research also suggests that by having two partners within the same organization, there will be a higher probability of intra-organizational conflict between the partners who may represent conflicting institutional rules and norms. One may argue that the need for a local partner is higher in the early stage of a firm's entry into a host market (Peng, 2003); as the firm learns more about the institutional environment of the host country, the need may be gradually reduced. As some Japanese firms just found out in the recent anti-Japanese demonstrations, however, being in China for a quarter of a century is not enough for them to remove their liability of foreignness (Zaheer, 1995).

The above analysis does not seem to offer a definitive conclusion. Agency and transaction cost theories lead to conflicting propositions. The choice between EJVs and WOSs, according to these perspectives, represents a tradeoff between lower transaction costs in an underdeveloped market and higher agency costs in a two or multi-party hierarchy. Exactly how much China's institutional environment has changed towards the reduction of transaction costs, so that a WOS is preferable over an EJV, is perhaps an empirical issue. Institutional theory itself provides mixed insights as to which mode of entry may lead to better results. Only the resource and capability perspectives are generally in favor of one mode over the other. For the purpose of statistical testing, we make the following proposition:

Hypothesis 3: On average, equity joint ventures perform better than wholly owned subsidiaries in China. 


\section{METHOD}

We rely on two large-sample surveys conducted by the Chinese National Bureau of Statistics to test our hypotheses. In recent years, the Bureau has conducted annual Industrial Censuses, which cover all enterprises operating in China, both domestic and foreign, that had annual sales revenues of US\$25,000 (RMB 200,000 yuan) or above in the past year. In other words, they aim to include all manufacturing firms except very small businesses. By law all businesses in China are required to cooperate in the censuses conducted by the Bureau. The Bureau started to engage in commercial activities in recent years through its commercial arms. Our data were purchased from one of these firms, Huatongren, which is one of the leading providers of business information in China.

For space limitation, we only used the 1998 and 2002 censuses - the first and last ones for which we have data. 1998 marks the twenties anniversary of China's reform and open-door policies, and was one year after China started to accelerate the ownership reform (Huang, 2003). From these two samples, we excluded firms that were established in 1998 and 2002, respectively, to make sure that all firms had had at least one year of operation. We also excluded firms classified as agricultural manufacturers. Further, we deleted cases with obviously inaccurate numbers (e.g. negative sales and negative total assets). There were roughly 140,000 and 160,000 enterprises, respectively, in each of these two samples. Research using this data source has appeared in a number of academic journals (Buckley, Clegg, \& Wang, 2002; Pan et al., 1999; Perkins, 1996). As Chow (1993) pointed out, statistics reported by the Bureau are largely accurate and internally consistent for empirical analysis.

We employed multiple-way ANOVA to test hypotheses 1 and 2, using a post-hoc procedure to derive pair-wise mean differences and their corresponding significance levels. The 
dependent variables in these tests are three absolute measures, Profit, Sales, and Assets, and three profitability ratios, Return on Sales (ROS), Return on Assets (ROA), and Profit per Employee (PPE) ${ }^{3}$. The ANOVA tests were conducted among the following groups: State-Owned Enterprises (SOEs), Collectively Owned Enterprises (COEs) ${ }^{4}$, Shareholding Enterprises (SHEs), Limited Liability Enterprises (LLEs), Privately Owned Enterprises (POEs), and Foreign-Invested Enterprises (FIEs), with age, size, location, and industry as control variables. The control variables were treated as fixed factors along with ownership (hence multiple-way ANOVA). Therefore, they are "control variables" only in a conceptual sense. Firm age is measured in years. We evenly divided all firms into four size groups based on the number of employees. Thus firm size is an interval scale ranging from 1 to 4 , with 4 representing the top $25^{\text {th }}$ percentile of firms. Location is a dummy variable coded 1 if a firm is located in a coastal province, and 0 if otherwise. We also included over four hundred 4-digit Chinese SICs to control for industry fixed effects. The age, size, and location variables and many of the industry dummies are significant but not reported here.

We then followed the above format to test hypothesis 3, with equity joint ventures (EJVs) and wholly owned subsidiaries (WOSs) as the classification groups. Although there are only two groups involved, we chose multiple-way ANOVA, instead of a simple t-test, because we wanted to "control" for the effects of age, size, location, and industry segments.

\section{RESULTS}

Table 2 lists in each cell the mean, standard deviation, minimum, and maximum, in that order, of the corresponding dependent variable, for the corresponding group. All F-tests are significant at the $\mathrm{p}<0.001$ level. Detailed pair-wise results from post-hoc analysis (Tamhane's T2 in SPSS) are listed in Appendix 1. We discuss the performance of each category of firms below. 
The SOEs. In 1998 (Table 2a), the SOEs had the lowest average profit level (\$1,350 US equivalent) among all groups of firms. In term of profitability, they had a negative and the lowest ROS (-0.246). They were the only group of firms that had a negative ROA $(-0.023)$ and a negative PPE (-\$206). By 2002 (Table 2b), their average profit level had risen to $\$ 298,000$, surpassing those of the COEs and POEs. Yet their profitability ratios remained to be the lowest among all firms (-0.159, -0.008 , and \$16). The number of SOEs included in the two surveys declined from 43,513 in 1998 to 22,737 in 2002, reflecting the changing reality in the Chinese economy.

$* * * * * * * * * * * * * * * * * * * * * * * * * * * * *$

Insert Tables $2 \mathrm{a}$ and $2 \mathrm{~b}$ about here

$* * * * * * * * * * * * * * * * * * * * * * * * * * * * *$

The Non-SOEs. The largest group of non-SOEs in 1998, the COEs, did surprisingly well in terms of the profitability ratios $(0.012,0.103$, and $\$ 844)$, and their relative standing remained largely unchanged in $2002(0.021,0.101$, and \$1,230), although their number declined from 43,415 to 24,236 . The SHEs had the highest average profit $(\$ 338,000)$ but a negative ROS (0.010) in 1998. Their ROA (0.050) and PPE (\$841) were relatively high. The ROS turned positive (0.017) in 2002. It appears that many former SOEs had been transformed into LLEs and POEs by 2002 , with the numbers of these two categories of firms rose substantially to 19,892 and 44,727, respectively. The POEs did rather well in 1998 in term of profitability. They had the highest ROS and ROA ratios ( 0.030 and 0.082 , respectively) in 2002 as well, although they remained to be the smallest in size ( $\$ 3,131,000$ in sales and $\$ 2,269,000$ in assets). The LLEs had the lowest performance among the non-SOEs in both years.

The FIEs. In 1998, the FIEs did not appear to have any significant advantage compared to local firms other than the SOEs. In 2002, they achieved a moderate increase in number (from 
$24,902$ to 32,751$)$, the highest profit level $(\$ 664,000)$, and the highest PPE $(\$ 2,200)$. The ROS and ROA ratios (0.007 and 0.046, respectively) both improved over those of $1998(-0.030$ and 0.023, respectively) but still lag behind some groups of domestic firms. Overall, there is no clear indication that the FIEs performed better than most Chinese firms.

Summarizing the above results, combined with a careful examination of the significance levels for pair-wise group mean differences in Appendices 1a and 1b, we can draw the following conclusions. First, the SOEs had the lowest performance levels, in terms of the profitability ratios, in both 1998 and 2002. Thus hypothesis 1 is supported. Second, compared to the nonSOEs, the FIEs performed better than the LLEs only, in terms of ROS and ROA, in 1998. In 2002, the situation was largely unchanged, although the difference between the FIEs and SHEs on ROA turned insignificant (Appendix 1b). Overall, there are no clear signs supporting hypothesis 2 . On the contrary, it appears that three categories of Chinese firms, the POEs, COEs, and SHEs, performed better than the FIEs to different extents.

Table 3 shows the results of mean comparisons between the EJVs and WOSs. It appears that the EJVs performed better than the WOSs on certain dimensions. In 1998, the EJVs had higher assets $(\mathrm{p}<0.05)$ and higher ROA $(\mathrm{p}<0.001)$. In 2002, the EJVs stayed ahead of the WOSs on these two measures $(\mathrm{p}<0.001$ for both assets and ROA) as well as on ROS $(p<0.05)$. Differences on other measures are largely insignificant. Hypothesis 3 thus received some support. It should be noted that while the numbers of both EJVs and WOS increased from 1998 to 2002, the latter rose much more rapidly, in both absolute number and percentage.

$* * * * * * * * * * * * * * * * * * * * * *$

Insert Tables 3 about here

$* * * * * * * * * * * * * * * * * * * * * *$ 


\section{DISCUSSION AND CONCLUSIONS}

That domestic Chinese firms are becoming increasingly competitive vis-a-vis multinational firms has received much anecdotal evidence in media and industry reports. An Asian Wall Street Journal article described China's consumer-goods market as characterized by fierce competition and eroding profit margins for small and medium foreign investors, especially because their local Chinese counterparts are gaining competitiveness. The author cited experts from Merrill Lynch and McKinsey to conclude that China is the most competitive (consumergoods) market in the world (Chang, 2002). Similarly, in a large survey conducted by Fortune (China) in 2002, 83 percent of the responding foreign firms considered increasing competition as a major challenge facing their firms, high over such institutional factors as governmental relations, labor management, and policy uncertainty (Jiang, 2002).

Our study provides large-sample statistics to confirm these informal reports. Three major findings are obtained from our data analysis and are worth further discussion. The first major finding is that the reformed SOEs and newly formed private firms have become rather competitive compared to the SOEs. After twenty years' reform, the various types of firms into which the former SOEs were transformed - the SHEs, LLEs, and POEs - have achieved evidently higher performance levels than the un-reformed SOEs. Although this finding itself is not surprising, this is perhaps the first time the positive profit outcome of reform in China is reported on such a large scale.

The second major finding, that many categories of domestic Chinese firms - the SHEs, COEs, and POEs - achieved higher performance than the FIEs, is counter-intuitive and falls beyond many people's expectation. Reform and open-door policies began at the same time after 1978. Twenty years ago the performance difference between Chinese and foreign firms was 
obvious. Since then, the domestic firms have made progress through reform and competition, as multinational firms gradually learned to cope with China's unique institutional setting and competitive environment. While the majority of people in China are concerned about the competitive pressures on domestic firms brought about by the multinationals as a result of China's entry into the WTO, our statistics show that such a concern is perhaps unwarranted. The only groups of domestic firms that lagged behind the FIEs in 2002 were the SOEs and LLEs. This result delivers a clear message, namely, ownership reform is the right way to go for the Chinese economy, and should help resolve the controversies on this issue in China since mid2004.

Among the non-SOEs, we found the POEs and COEs to be the best performers, which is somewhat surprising, as one may expect the SHEs, the firms that most resemble modern corporations in a free economy, to be the leading enterprises in China. From an ownership perspective, however, the SHEs may still involve state equity, either in a majority or minority position. The SHEs and LLEs are the two categories of firms into which the larger SOEs were transformed. The state typically retains some ownership in these firms and exerts substantial influences in the post-reform era. As a result, agency problems such as insiders' control and expropriation of minority interests are common among these firms (Dharwadkar, George, \& Brandes, 2000, Young, Peng, Ahlstrom, \& Bruton, 2002). As they are typically larger than the POEs, they may also be expected to share some policy burdens by the government, which causes inefficiencies. If we further consider the fact that some of their best physical and human assets had been separated or spun off to form joint ventures with multinational firms (Buck, Filatotchev, Nolan, \& Wright, 2000), their disadvantages become clear. The POEs, although small, are tightly controlled by private owners and very much profit-oriented. It should not too surprising that they 
had the highest ROS in both years. The advantages of COEs, which include numerous townshipvillage enterprises (TVEs), have been discussed extensively in the literature (e.g. Che \& Qian, 1998; Jin \& Qian, 1998) and will not be repeated here.

The last major finding of this study is that the EJVs are still leading the FIEs in terms of the profitability ratios. Despite the strategic change made by many multinational firms incumbents as well as newcomers to China - to opt for wholly owned subsidiaries, the EJVs actually had higher performance, based on some measures, than the WOSs, and even more so in 2002 than in 1998. This result, combined with the fact that the FIEs as a whole did not do better than the domestic Chinese firms, has important implications for multinational firms. It appears that multinational firms today still have a relatively high degree of liability of foreignness in China, and partnering with a local firm remains to be a good strategy to deal with this situation. In addition to the old argument that a local partner can bridge local knowledge, legitimacy, and consumers to the multinational firm, the higher competitiveness of Chinese firms found in this study suggests that local firms can make further contributions to the success of joint ventures, perhaps in terms of valuable resources and improved capabilities, and that the integration inside the EJVs today will be easier than ever before because of the progress local firms have made in the past two decades or so.

Generally, we send a warning signal to multinational firms inside, or considering to enter, the China market. It seems that domestic Chinese firms are learning faster in the competition than the foreign firms. If this trend continues, not only the FIEs will lose ground in the domestic market, but also their parents may soon be confronted with a large number of competitors from China in the international market. The FIEs, of course, still have their traditional advantages in capital, technology, managerial practice, and brand reputation. Furthermore, FIEs had the highest 
profit level per firm $(\$ 664,000)$ and the highest profit level per employee $(\$ 2,200)$ in 2002 . With adequate financial resources and excellent training programs, multinational firms can attract, retain, and promote the best talents in China, further strengthening their competitive advantage in the quality of human resources.

Finally, we note that this study has its limitations. Due to data availability, we used only the 1998 and 2002 Industrial Censuses information. Thus we missed the firms that failed or exited before 1998; the firms that are included for analysis may be winners of survival tests over years. This is a common limitation in research on firm performance, and we were not able to remove this problem. Also, we were not able to identify, among the non-SOEs, the firms that were transformed from former SOEs, and thus unable to assess the effect of ownership reform directly, or to conduct a longitudinal analysis. We hope that the inclusion of an age control, and the fact that our empirical analysis was based on nearly the population of firms in China at two different points of time, will make up for these deficiencies. 


\section{NOTES:}

${ }^{1}$ In the summer of 2004, Professor Larry H. P. Lang of the Chinese University of Hong Kong sparked a major controversy in China by charging China's emerging class of entrepreneurs and professional managers of stealing state assets in the process of SOE reform and privatization. He argued that ownership reform has not strengthened the former SOEs, but instead is detrimental to public interests. In response, China's elite entrepreneurs, allied with liberal economists, defended the reform as well as their own behavior fiercely. For many months the financial media were dominated by this national debate. Our study provides a partial answer to the controversy.

${ }^{2}$ For instance, a recent report on the current state of the Chinese automobile industry held that partnering with foreign manufacturers has made Chinese automakers highly dependent on foreign technology, because multinational firms would insist that the Chinese partner give up its $\mathrm{R} \& \mathrm{D}$ activities as a prerequisite for forming a joint venture.

${ }^{3}$ Although we refer to the PPE as a ratio, it is reported as the absolute profit amount per employee.

${ }^{4}$ Collectively owned enterprises were part of the planned economy in the pre-reform days. Although this form of ownership has been retained, today's COEs are part of the market-oriented economy. They include, among others, China's active township-village enterprises (TVEs). 


\section{REFERENCES}

Barney, J. (1991). Firm resources and sustained competitive advantage. Journal of Management, 17(1): 99-120.

Beamish, P. W. (1993). The characteristics of joint ventures in the People's Republic of China. Journal of International Marketing, 1(2): 29-48.

Beamish, P. W., \& Banks, J. C. (1987). Equity joint ventures and the theory of the multinational enterprise. Journal of International Business Studies, 18(2): 1-16.

Birkinshaw, J., \& Hood, N. (1998). Multinational subsidiary evolution: Capability and charter change in foreign-owned subsidiary companies. Academy of Management Review, 23(4): 773-795.

Buck, T., Filatotchev, I., Nolan, P., \& Wright, M. (2000). Different paths of economic reform in Russia and China: Causes and consequences. Journal of World Business, 35(4): 379-400.

Buckley, P. J., \& Casson, M. C. (1976). The future of the multinational enterprise. London: Macmillan Press.

Buckley, P. J., Clegg, J., \& Wang, C. (2002). The impact of inward FDI on the performance of Chinese manufacturing firms. Journal of International Business Studies, 33(4): 637-655.

Chang, L. (2002). China: Challenges ahead. The Asian Wall Street Journal, October 13.

Che, J., \& Qian, Y. (1998). Instituional environment, community government, and corporate governance: Understanding China's township-village enterprises. Journal of Law, Economics, and Organization, 14(1): 1-23.

Child, J., \& Tse, D. K. (2001). China's transition and its implications for international business. Journal of International Business Studies, 32(1): 5-21.

Chow, G. C. (1993). Capital formation and economic growth in China. Quarterly Journal of Economics, 108(3): 809-842.

Delios, A., \& Beamish, P. W. (2001). Survival and profitability: The roles of experience and intangible assets in foreign subsidiary performance. Academy of Management Journal, 44(5): 1028-1038.

Demsetz, H. (1983). The structure of ownership and the theory of the firm. Journal of Law \& Economics, 26: 375-390.

Dharwadkar, R., George, G., \& Brandes, P. (2000). Privatization in emerging economics: An agency theory perspective. Academy of Management Review, 25: 650-669.

DiMaggio, P. J., \& Powell, W. W. (1983). The iron cage revisited: Institutional isomorphism and collective rationality in organizational fields. American Sociological Review, 48: 147-160.

Dunning, J. H. (1981). International production and the multinational enterprise. London: Allen \& Unwin. 
Fama, E. F., \& Jensen, M. C. (1983). Separation of ownership and control. Journal of Law \& Economics, 26: 301-325.

Ghoshal, S., \& Barlett, C. A. (1990). The multinational corporations as an interorganizational network. Academy of Management Review, 15(4): 603-625.

Hymer, S. H. (1976). The international operations of national firms: A study of direct investment. Cambridge, MA: MIT Press.

Hoskisson R. E., Eden, L., Lau, C. M., \& Wright, M. (2000). Strategy in emerging economies. Academy of Management Journal, 43: 249-267.

Huang, Y. (2003). Selling China: Foreign direct investment during the reform era. Cambridge, UK: Cambridge University Press.

Jiang, W. (2002). Impression of China - 2002 foreign investments survey. Fortune (China), 41(May): 10-17.

Jin, H., \& Qian, Y. (1998). Public versus private ownership of firms: Evidence from rural China. Quarterly Journal of Economics, 113(3): 773-808.

Kostova, T., \& Zaheer, S. (1999). Organizational legitimacy under conditions of complexity: The case of the multinational enterprise. Academy of Management Review, 24: 64-81.

Lane, P., Salk, J., \& Lyles, M. (2001). Absorptive capacity, learning, and performance in international joint ventures. Strategic Management Journal, 22: 1139-1161.

Li, J., Qian, G., Lam, K., \& Wang, D. (2000). Breaking into China: Strategic considerations for multinational corporations. Long Range Planning, 33: 673-687.

Lin, J. Y., Cai, F., \& Li, Z. (1998). Competition, policy burdens, and state-owned enterprise reform," The American Economic Review, 88(2): 422-427.

Lin, J. Y., \& Tan, G. (1999). Policy burdens, accountability, and the soft budget constraint. AEA Papers and Proceedings, 89(2): 426-431.

Luo, Y. (1997). Partner selection and venturing success: The case of joint ventures with firms in the People's Republic of China. Organization Science, 8(6): 648-662.

Luo, Y., \& Peng, M. W. (1999). Learning to compete in a transition economy: Experience, environment, and performance. Journal of International Business Studies, 30(2): 269-295.

Luo, Y., Shenkar, O. \& Nyaw, M. (2001). A dual parent perspective on control and performance in international joint ventures: Lessons from a developing economy. Journal of International Business Studies, 32(1): 41-58.

Lyles, M. A., \& Salk, J. E. (1996). Knowledge acquisition from foreign parents in international joint ventures. Journal of International Business Studies, 27(5): 877-904.

Makino S., \& Delios, A. (1996). Local knowledge transfer and performance: Implications for alliance formation in Asia. Journal of International Business Studies, 27(5): 905-927.

Mar, P., \& Young, M. N. (2001). Corporate governance in transition economies: A case study of two Chinese airlines. Journal of World Business, 36(3): 280-302. 
Meyer, J. W., \& Rowan, B. (1977). Institutionalized organizations: Formal structure as myth and ceremony. American Journal of Sociology, 83: 340-363.

Meyer, K. E. (2001). Institutions, transaction costs, and entry mode choice in Eastern Europe. Journal of International Business Studies, 32: 357-367.

Meyer, K. E., \& Peng, M. W. (2005). Probing theoretically into Central and Eastern Europe: Transactions, resources, and institutions. Journal of International Business Studies, forthcoming.

Nee V. (1992). Organizational dynamics of market transition: Hybrid forms, property rights, and mixed economy in China. Administrative Science Quarterly, 37: 1-27.

Nee, V., \& Matthews, R. (1996). Market transition and societal transformation in reforming state socialism. Annual Review of Sociology, 22: 401-435.

Nohria, N., \& Ghoshal, S. (1994). Differentiated fit and shared values: Alternatives for managing headquarters-subsidiary relations. Strategic Management Journal, 15: 491-502.

North, D. C. (1990). Institutions, institutional change, and economic performance. Cambridge, UK: Cambridge University Press.

Oliver, C. (1991). Strategic responses to institutional processes. Academy of Management Review, 16(1): 145-179.

O'neill, M. (1999). Fate of state sector hinges on Plenum. The South China Morning Post, September 20, page 1 .

Pan, Y., \& Chi, P. S. K. (1999). Financial performance and survival of multinational corporations in China. Strategic Management Journal, 20(4): 359-374.

Pan, Y., Li, S., \& Tse, D. K. (1999). The impact of order and mode of market entry on profitability and market share. Journal of International Business Studies, 30(1): 81-104.

Peng, M. W. (2003). Institutional transitions and strategic choices. Academy of Management Review, 28(2): 275-296.

Peng, M. W., \& Luo, Y. (2000). Managerial ties and firm performance in a transition economy: The nature of a micro-macro link. Academy of Management Journal, 43(3): 486-501.

Perkins, F. C. (1996). Productivity performance and priorities for the reform of China's stateowned enterprises. Journal of Development Studies, 32(3): 414-444.

Prahalad, C. K., \& Hamel, G. (1990). The core competence of the corporation. Harvard Business Review, 68: 79 - 93.

Qian, Y. (1996). Enterprise reform in China: Agency problems and political control. Economics of Transition, 4(2): 427-447.

Roth, K., \& O’Donnell, S. (1996). Foreign subsidiary compensation strategy: An agency theory perspective. Academy of Management Journal, 39(3): 678-703.

Scott, W. R. (1995). Institutions and organizations. Thousand Oaks, CA: Sage. 
Shenkar, O. (1990). International joint ventures problems in China: Risks and remedies. Long Range Planning, 23(3): 82-90.

Steensma, K., \& Lyles, M. (2000). Explaining IJV survival in a transitional economy through social exchange and knowledge-based perspectives. Strategic Management Journal, 21: 831-851.

Tsang, E. (1998). Can guanxi be a source of sustained competitive advantage for doing business in China? Academy of Management Executive, 12(2): 64-73.

Walsh, J. P., Wang, E., \& Xin, K. R. (1999). Same bed, different dreams: Working relationships in Sino-American joint ventures. Journal of World Business, 34(1): 69-93.

Wernerfelt, B. (1984). A resource-based view of the firm. Strategic Management Journal, 5: 171-180.

Westney, D. E. (1993). Institutionalization theory and the multinational corporation. In S. Ghoshal \& D. E. Westney (Eds.), Organization theory and the multinational corporation: 53-76. New York: St. Martin's Press.

Williamson, O. E. (1985). The Economic Institutions of Capitalism. New York: Free Press.

Vanhonacker, W. R. (1997). Entering China: An unconventional approach. Harvard Business Review, 75(2): 130-140.

Xu, D., Pan, Y., \& Beamish, P. W. (2004). The Effect of regulative and normative distances on MNE ownership and expatriate strategies. Management International Review, 44(3): 285307.

Xu, D., \& Shenkar, O. (2002). Institutional distance and the multinational enterprise. Academy of Management Review, 27: 608-618.

Young, M. N., Peng, M. W., Ahlstrom, D., \& Bruton, G. D. (2002). Governing the corporation in emerging economies: A principal-principal perspective. Academy of Management Best Paper Proceedings, BPS: E1.

Zaheer, S. (1995). Overcoming the liability of foreignness. Academy of Management Journal, 38(2): 341-363.

Zeng, M., \& Williamson, P. J. (2003). The hidden dragons. Harvard Business Review, 81(10): 92-99. 
Table 2a. Operational Performance of All Groups of Firms in 1998

\begin{tabular}{|c|c|c|c|c|c|c|c|}
\hline $\begin{array}{l}\text { Dependent } \\
\text { Variable }\end{array}$ & SOES & COEs & SHEs & LLEs & POEs & FIEs & F-Test \\
\hline \multirow[t]{4}{*}{ Profit } & 1.35 & 102 & 338 & 193 & 84.1 & 214 & $\mathrm{~F}=32.19$ \\
\hline & 4563 & 758 & 3046 & 4163 & 477 & 4802 & $\mathrm{P}<0.001$ \\
\hline & -188734 & -49667 & -41535 & -39459 & -16887 & -108087 & \\
\hline & 697290 & 67016 & 189385 & 267936 & 27081 & 366954 & \\
\hline \multirow[t]{4}{*}{ Sales } & 5872 & 3164 & 5765 & 8201 & 2253 & 7611 & $\mathrm{~F}=35.08$ \\
\hline & 50910 & 12717 & 25642 & 39626 & 4330 & 36210 & $\mathrm{P}<0.001$ \\
\hline & 25 & 25 & 25 & 25 & 25 & 27 & \\
\hline & 3599675 & 2033198 & 1191277 & 1535913 & 157273 & 3150485 & $\mathrm{~F}=38.16$ \\
\hline \multirow[t]{4}{*}{ Assets } & 12968 & 3094 & 8862 & 16916 & 1785 & 10256 & $\mathrm{P}<0.001$ \\
\hline & 113476 & 10680 & 41316 & 93756 & 3942 & 51638 & \\
\hline & 12 & 12 & 13 & 19 & 12 & 13 & \\
\hline & 11300000 & 1133704 & 2236054 & 2847927 & 130134 & 3718626 & $\mathrm{~F}=228.16$ \\
\hline \multirow[t]{4}{*}{ ROS } & -0.246 & 0.012 & -0.010 & -0.033 & 0.026 & -0.030 & $\mathrm{P}<0.001$ \\
\hline & 1.560 & 0.208 & 1.680 & 0.387 & 0.132 & 0.364 & \\
\hline & -97.300 & -19.800 & -167.000 & -14.400 & -5.730 & -13.500 & \\
\hline & 29.900 & 7.660 & 7.950 & 2.250 & 1.890 & 13.500 & \\
\hline \multirow[t]{4}{*}{ ROA } & -0.023 & 0.103 & 0.050 & 0.019 & 0.103 & 0.023 & $\mathrm{~F}=997.15$ \\
\hline & 0.164 & 0.326 & 0.165 & 0.110 & 0.296 & 0.195 & $\mathrm{P}<0.001$ \\
\hline & -7.830 & -5.410 & -1.190 & -1.110 & -1.200 & -7.140 & \\
\hline & 13.900 & 19.700 & 8.130 & 1.990 & 16.000 & 18.100 & \\
\hline \multirow[t]{4}{*}{ PPE } & -0.206 & 0.844 & 0.841 & 0.509 & 0.933 & 0.417 & $\mathrm{~F}=151.63$ \\
\hline & 4.110 & 3.470 & 5.850 & 5.740 & 2.950 & 11.000 & $\mathrm{P}<0.001$ \\
\hline & -161 & -99 & -36 & -32 & -26 & -676 & \\
\hline & 367 & 256 & 475 & 357 & 149 & 32 & \\
\hline $\mathrm{N}$ & 43513 & 43415 & 12322 & 6164 & 9138 & 24902 & \\
\hline
\end{tabular}

Note: Amounts are in thousand U.S. dollars for all measures except for the ratios. In each cell, the first number is the mean, the second row is the standard deviation, the third row is the minimum, and the fourth row is the maximum. 
Table 2b. Operational Performance of All Groups of Firms in 2002

\begin{tabular}{|c|c|c|c|c|c|c|c|}
\hline $\begin{array}{l}\text { Dependent } \\
\text { Variable }\end{array}$ & SOEs & COEs & $\overline{\text { SHEs }}$ & LLEs & POEs & FIEs & F-Test \\
\hline \multirow[t]{4}{*}{ Profit } & 298 & 190 & 627 & 430 & 129 & 664 & $\mathrm{~F}=28.54$ \\
\hline & 6428 & 1485 & 7325 & 4754 & 599 & 7559 & $\mathrm{P}<0.001$ \\
\hline & -61457 & -4964 & -52016 & -134593 & -9117 & -91937 & \\
\hline & 581536 & 128166 & 740330 & 382970 & 51591 & 669431 & \\
\hline \multirow[t]{4}{*}{ Sales } & 9973 & 4194 & 11969 & 10813 & 3131 & 11487 & $\mathrm{~F}=32.38$ \\
\hline & 98807 & 29583 & 79837 & 60857 & 7678 & 73414 & $\mathrm{P}<0.001$ \\
\hline & 25 & 25 & 25 & 25 & 25 & 25 & \\
\hline & 6033311 & 3783528 & 4221264 & 2924314 & 475501 & 5666506 & \\
\hline \multirow[t]{4}{*}{ Assets } & 18944 & 3526 & 15339 & 17540 & 2269 & 11451 & $\mathrm{~F}=37.42$ \\
\hline & 164168 & 22211 & 98656 & 113036 & 6628 & 56683 & $\mathrm{P}<0.001$ \\
\hline & 13 & 12 & 28 & 12 & 14 & 13 & \\
\hline & 9371782 & 2447658 & 7688434 & 6731044 & 482610 & 3703613 & \\
\hline \multirow[t]{4}{*}{ ROS } & -0.159 & 0.021 & 0.017 & -0.0006 & 0.030 & 0.007 & $F=202.53$ \\
\hline & 1.120 & 0.375 & 0.307 & 0.715 & 0.292 & 0.350 & $\mathrm{P}<0.001$ \\
\hline & -87.900 & -42.600 & -20.600 & -69.200 & -58.600 & -23.800 & \\
\hline & 11.800 & 2.040 & 3.560 & 43.200 & 2.100 & 22.400 & \\
\hline \multirow[t]{4}{*}{ ROA } & -0.008 & 0.101 & 0.053 & 0.037 & 0.082 & 0.046 & $\mathrm{~F}=298.51$ \\
\hline & 0.115 & 0.283 & 0.130 & 0.115 & 0.172 & 0.473 & $\mathrm{P}<0.001$ \\
\hline & -5.490 & -2.400 & -4.330 & -2.000 & -2.270 & -56.700 & \\
\hline & 4.710 & 20.900 & 3.61 & 3.3 & 9.760 & 55.000 & \\
\hline \multirow[t]{4}{*}{ PPE } & 0.016 & 1.230 & 1.360 & 1.470 & 1.140 & 2.200 & $\mathrm{~F}=42.74$ \\
\hline & 5.490 & 3.700 & 5.650 & 35.700 & 4.100 & 17.600 & $\mathrm{P}<0.001$ \\
\hline & -264 & -128 & -104 & -149 & -35 & -221 & \\
\hline & 334 & 116 & 223 & 4947 & 337 & 1926 & \\
\hline $\mathrm{N}$ & 22737 & 24236 & 14836 & 19892 & 44727 & 32751 & \\
\hline
\end{tabular}

Note: Amounts are in thousand U.S. dollars for all measures except for the ratios. In each cell, the first number is the mean, the second row is the standard deviation, the third row is the minimum, and the fourth row is the maximum. 
Table 3. Operational Performance of EJVs and WOSs

\begin{tabular}{|c|c|c|c|c|c|c|}
\hline & \multicolumn{3}{|c|}{ Year 1998} & \multicolumn{3}{|c|}{ Year 2002} \\
\hline $\begin{array}{l}\text { Dependent } \\
\text { Variables }\end{array}$ & EJVs & WOSs & $\mathrm{F}$ test & EJVs & WOSs & F test \\
\hline \multirow[t]{4}{*}{ Profit } & 230 & 177 & $\mathrm{~F}=0.73$ & 746 & 549 & $\mathrm{~F}=0.05$ \\
\hline & 5015 & 4286 & $\mathrm{P}=0.394$ & 8921 & 5098 & $\mathrm{P}=0.940$ \\
\hline & -108087 & -30626 & & -91937 & -86258 & \\
\hline & 366953 & 315394 & & 669431 & 358390 & \\
\hline \multirow[t]{4}{*}{ Sales } & 7618 & 7594 & $\mathrm{~F}=2.91$ & 11317 & 11721 & $\mathrm{~F}=2.70$ \\
\hline & 35156 & 38471 & $\mathrm{P}=0.088$ & 66144 & 82441 & $\mathrm{P}=0.100$ \\
\hline & 27 & 31 & & 25 & 25 & \\
\hline & 3150485 & 2196985 & & 4533160 & 5666506 & \\
\hline \multirow[t]{4}{*}{ Assets } & 10705 & 9249 & $\mathrm{~F}=5.24$ & 11703 & 11100 & $F=12.60$ \\
\hline & 52759 & 49016 & $\mathrm{P}=0.022$ & 54697 & 59325 & $\mathrm{P}<0.001$ \\
\hline & 13 & 24 & & 13 & 21 & \\
\hline & 3718626 & 2478293 & & 3703612 & 3384195 & \\
\hline \multirow[t]{4}{*}{ ROS } & -0.033 & -0.024 & $\mathrm{~F}=0.12$ & 0.008 & 0.006 & $\mathrm{~F}=5.32$ \\
\hline & 0.395 & 0.278 & $\mathrm{P}=0.727$ & 0.379 & 0.304 & $\mathrm{P}=0.020$ \\
\hline & -13.542 & -5.001 & & -23.830 & -16.390 & \\
\hline & 4.789 & 13.482 & & 22.443 & 5.220 & \\
\hline \multirow[t]{4}{*}{ ROA } & 0.026 & 0.015 & $F=26.86$ & 0.052 & 0.039 & $\mathrm{~F}=8.86$ \\
\hline & 0.196 & 0.191 & $\mathrm{P}<0.001$ & 0.421 & 0.535 & $\mathrm{P}<0.001$ \\
\hline & -3.075 & -7.140 & & -2.471 & -56.727 & \\
\hline & 18.055 & 4.653 & & 55.043 & 9.681 & \\
\hline \multirow[t]{4}{*}{ PPE } & 0.505 & 0.219 & $\mathrm{~F}=0.58$ & 2.295 & 2.063 & $\mathrm{~F}=0.73$ \\
\hline & 12.188 & 7.724 & $\mathrm{P}=0.445$ & 15.130 & 20.467 & $\mathrm{P}=0.390$ \\
\hline & -676.022 & -156.575 & & -221.266 & -125.801 & \\
\hline & 325.000 & 156.221 & & 1165.031 & 1925.589 & \\
\hline $\mathrm{N}$ & 17360 & 7737 & & 19120 & 13790 & \\
\hline
\end{tabular}

Note: Amounts are in thousand U.S. dollars for all measures except for the ratios. In each cell, the first number is the mean, the second row is the standard deviation, the third row is the minimum, and the fourth row is the maximum. 
Appendix 1a. Pair-Wise Comparisons of Performance for Different Ownership Categories in 1998

\begin{tabular}{|c|c|c|c|c|c|c|c|}
\hline Ownership (I) & Ownership (J) & \multicolumn{6}{|c|}{ Mean Difference (I-J) } \\
\hline & & Profit & Sales & Assets & $\mathrm{ROS}$ & ROA & PPE \\
\hline \multirow{5}{*}{$\begin{array}{l}\text { State-Owned } \\
\text { Enterprise } \\
\text { (SOE) }\end{array}$} & $\mathrm{COE}$ & $-101 * *$ & $2758 * * *$ & $9994 * * *$ & $-.259 * * *$ & $-.126 * * *$ & $-1.054 * * *$ \\
\hline & SHE & $-338 * * *$ & 139 & $4207 * * *$ & $-.236 * * *$ & $-.074 * * *$ & $-1.052 * * *$ \\
\hline & LLE & $-187 * *$ & $-2277 * * *$ & $-3879 * *$ & $-.212 * * *$ & $-.042 * * *$ & $-.714 * * *$ \\
\hline & POE & $-79 * * *$ & $3676 * * *$ & $11318 * * *$ & $-.273 * * *$ & $-.127 * * *$ & $-1.144 * * *$ \\
\hline & FIE & $-213 * *$ & $-1709 * * *$ & $2804 * * *$ & $-.215 * * *$ & $-.046 * * *$ & $-.633 * * *$ \\
\hline \multirow{5}{*}{$\begin{array}{l}\text { Collectively } \\
\text { Owned Enterprise } \\
(\mathrm{COE})\end{array}$} & SOE & $101 * * *$ & $-2758 * * *$ & $-9994 * * *$ & $.2594 * * *$ & $.126 * * *$ & $1.054 * * *$ \\
\hline & SHE & $-237 * * *$ & $-2618 * * *$ & $-5786 * * *$ & .023 & $.052 * * *$ & .001 \\
\hline & LLE & -85 & $-5035 * * *$ & $-13873 * * *$ & $.046 * *$ & $.083 * * *$ & $.339 * * *$ \\
\hline & POE & $21 * * *$ & $918 * * *$ & $1324 * * *$ & $-.013 * * *$ & -.0006 & -.090 \\
\hline & FIE & $-112 * * *$ & $-4467 * * *$ & $-7189 * * *$ & $.043 * * *$ & $.079 * * *$ & $.421 * * *$ \\
\hline \multirow{5}{*}{$\begin{array}{l}\text { Shareholding } \\
\text { Enterprise } \\
\text { (SHE) }\end{array}$} & SOE & $338 * * *$ & -139 & $-4207 * * *$ & $.236 * * *$ & $.074 * * *$ & $1.052 * * *$ \\
\hline & $\mathrm{COE}$ & $237 * * *$ & $2618 * * *$ & $5786 * * *$ & -.023 & $-.052 * * *$ & -.001 \\
\hline & LLE & 151 & $-2416 * * *$ & $-8086 * * *$ & .023 & $.031 * * *$ & $.338 * * *$ \\
\hline & POE & $258.59 * * *$ & $3537 * * *$ & $7111 * * *$ & -.037 & $-.053 * * *$ & -.092 \\
\hline & FIE & $125 * * *$ & $-1848 * * *$ & $-1402 *$ & .020 & $.027 * * *$ & $.419 * * *$ \\
\hline \multirow{5}{*}{$\begin{array}{l}\text { Limited Liability } \\
\text { Enterprise } \\
\text { (LLE) }\end{array}$} & SOE & $187 * *$ & $2277 * * *$ & $3879 * *$ & $.212 * * *$ & $.042 * * *$ & $.714 * * *$ \\
\hline & $\mathrm{COE}$ & 85 & $5035 * * *$ & $13873 * * *$ & $-.046 * * *$ & $-.083 * * *$ & $-.339 * * *$ \\
\hline & SHE & -151 & $2416 * * *$ & $8086 * * *$ & -.023 & $-.031 * * *$ & $-.338 * * *$ \\
\hline & POE & 107 & $5954 * * *$ & $15197 * * *$ & $-.060 * * *$ & $-.084 * * *$ & $-.430 * * *$ \\
\hline & FIE & -26 & 568 & $6683 * * *$ & -.003 & -.004 & .081 \\
\hline \multirow{5}{*}{$\begin{array}{l}\text { Privately Owned } \\
\text { Enterprise } \\
\text { (POE) }\end{array}$} & SOE & $79 * * *$ & $-3676 * * *$ & $-11318 * * *$ & $.273 * * *$ & $.127 * * *$ & $1.144 * * *$ \\
\hline & $\mathrm{COE}$ & $-21 * * *$ & $-918 * *$ & $-1324 * * *$ & $.013 * * *$ & .0006 & .0903 \\
\hline & SHE & $-258 * * *$ & $-3537 * * *$ & $-7111 * * *$ & .037 & $.053 * * *$ & .0922 \\
\hline & LLE & -107 & $-5954 * * *$ & $-15197 * * *$ & $.060 * * *$ & $.084 * * *$ & $.430 * * *$ \\
\hline & FIE & $-133 * * *$ & $-5385 * * *$ & $-8513 * * *$ & $.057 * * *$ & $.080 * * *$ & $.511 * * *$ \\
\hline \multirow{5}{*}{$\begin{array}{l}\text { Foreign-Invested } \\
\text { Enterprise } \\
\text { (FIE) }\end{array}$} & SOE & $213 * * *$ & $1709 * * *$ & $-2804 * * *$ & $.215 * * *$ & $.046 * * *$ & $.633 * * *$ \\
\hline & $\mathrm{COE}$ & $112 * * *$ & $4467 * * *$ & $7189 * * *$ & $-.043 * * *$ & $-.079 * * *$ & $-.421 * * *$ \\
\hline & SHE & $-125 * *$ & $1848 * * *$ & $1402 *$ & -.020 & $-.027 * * *$ & $-.419 * * *$ \\
\hline & LLE & 26 & -568 & $-6683 * * *$ & .003 & .004 & -.081 \\
\hline & POE & $133 * * *$ & $5385 * * *$ & $8513 * * *$ & $-.057 * * *$ & $-.080 * * *$ & $-.511 * * *$ \\
\hline
\end{tabular}

Note: $* * *$ The mean difference is significant at the 0.01 level, ${ }^{* *}$ significant at 0.05 level, ${ }^{*}$ significant at 0.10 level. 
Appendix 1b. Pair-Wise Comparisons of Performance for Different Ownership Categories in 2002

\begin{tabular}{|c|c|c|c|c|c|c|c|}
\hline Ownership (I) & Ownership (J) & \multicolumn{6}{|c|}{ Mean Difference (I-J) } \\
\hline & & Profit & Sales & Assets & $\mathrm{ROS}$ & ROA & PPE \\
\hline State-Owned & $\mathrm{COE}$ & 100 & $5580 * * *$ & $15044 * * *$ & $-.180 * * *$ & $-.109 * * *$ & $-1.213 * * *$ \\
\hline Enterprise & SHE & $-337 * * *$ & -2205 & 3234 & $-.176 * * *$ & $-.062 * * *$ & $-1.339 * * *$ \\
\hline$(\mathrm{SOE})$ & LLE & -138 & -978 & 1255 & $-.158 * * *$ & $-.046 * * *$ & $-1.456 * * *$ \\
\hline & POE & $161 * * *$ & $6649 * * *$ & $16310 * * *$ & $-.189 * * *$ & $-.091 * * *$ & $-1.128 * * *$ \\
\hline & FIE & $-375 * * *$ & -1732 & $7101 * *$ & $-.166 * * *$ & $-.055 * * *$ & $-2.185 * * *$ \\
\hline Collectively & SOE & -100 & $-5580 * * *$ & $-15044 * * *$ & $.180 * * *$ & $.109 * * *$ & $1.213 * * *$ \\
\hline Owned Enterprise & SHE & $-437 * * *$ & $-7786 * * *$ & $-11809 * * *$ & .004 & $.047 * * *$ & -.126 \\
\hline$(\mathrm{COE})$ & LLE & $-239 * * *$ & $-6559 * * *$ & $-13788 * * *$ & $.022 * * *$ & $.063 * * *$ & -.242 \\
\hline & POE & $60 * * *$ & $1069 * * *$ & $1266 * * *$ & $-.008 * * *$ & $.018 * * *$ & $.084 *$ \\
\hline & FIE & $-476 * * *$ & $-7312 * * *$ & $-7943 * *$ & $.014 * * *$ & $.054 * * *$ & $-.972 * * *$ \\
\hline Shareholding & $\mathrm{SOE}$ & $337 * * *$ & 2205 & -3234 & $.176 * * *$ & $.062 * * *$ & $1.339 * * *$ \\
\hline Enterprise & $\mathrm{COE}$ & $437 * * *$ & $7786 * * *$ & $11809 * * *$ & -.004 & $-.047 * * *$ & .126 \\
\hline (SHE) & LLE & $198 *$ & 1226 & -1978 & $.018 * *$ & $.016 * * *$ & -.116 \\
\hline & POE & $498 * * *$ & $8855 * * *$ & $13076 * * *$ & $-.012 * * *$ & $-.028 * * *$ & $.211 * * *$ \\
\hline & FIE & -38 & 473 & $3866 * * *$ & $.009 * * *$ & .007 & $-.845 * * *$ \\
\hline Limited Liability & SOE & 138 & 978 & -1255 & $.158 * * *$ & $.046 * * *$ & $1.456 * * *$ \\
\hline Enterprise & $\mathrm{COE}$ & $239 * * *$ & $6559 * * *$ & $13788 * * *$ & $-.022 * * *$ & $-.063 * * *$ & .242 \\
\hline (LLE) & SHE & $-198 *$ & -1226 & 1978 & $-.018 * *$ & $-.016 * * *$ & .116 \\
\hline & POE & $300 * * *$ & $7628 * * *$ & $15055 * * *$ & $-.031 * * *$ & $-.045 * * *$ & .327 \\
\hline & FIE & $-237 * * *$ & -753 & $5845 * * *$ & -.008 & $-.009 * *$ & -.729 \\
\hline Privately Owned & SOE & $-161 * * *$ & $-6649 * * *$ & $-16310 * * *$ & $.189 * * *$ & $.091 * * *$ & $1.128 * * *$ \\
\hline Enterprise & $\mathrm{COE}$ & $-60 * * *$ & $-1069 * * *$ & $-1266 * * *$ & $.008 * *$ & $-.018 * * *$ & $-.084 *$ \\
\hline (POE) & SHE & $-498 * * *$ & $-8855 * * *$ & $-13076 * * *$ & $.012 * * *$ & $.028 * * *$ & $-.211 * * *$ \\
\hline & LLE & $-300 * * *$ & $-7628 * * *$ & $-15055 * * *$ & $.031 * * *$ & $.045 * * *$ & -.327 \\
\hline & FIE & $-537 * * *$ & $-8381 * * *$ & $-9209 * * *$ & $.022 * * *$ & $.036 * * *$ & $-1.057 * * *$ \\
\hline Foreign-Invested & SOE & $375 * * *$ & 1732 & $-7101 * * *$ & $.166 * * *$ & $.055 * * *$ & $2.185 * * *$ \\
\hline Enterprise & $\mathrm{COE}$ & $476 * * *$ & $7312 * * *$ & $7943 * * *$ & $-.014 * * *$ & $-.054 * * *$ & $.972 * * *$ \\
\hline (FIE) & SHE & 38 & -473 & $-3866 * * *$ & $-.009 * *$ & -.007 & $.845 * * *$ \\
\hline & LLE & $237 * * *$ & 753 & $-5845 * * *$ & .008 & $.009 * *$ & .729 \\
\hline & POE & $537 * * *$ & $8381 * * *$ & $9209 * * *$ & $-.022 * * *$ & $-.036 * * *$ & $1.057 * * *$ \\
\hline
\end{tabular}

Note: $* * *$ The mean difference is significant at the 0.01 level, $* *$ significant at 0.05 level, $*$ significant at 0.10 level. 